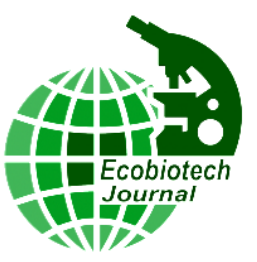

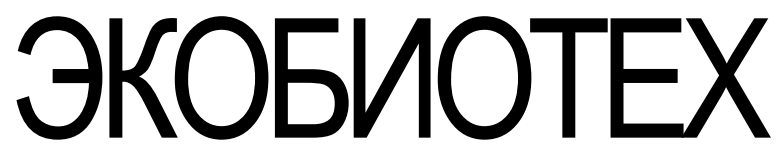

ISSN 2618-964X http://ecobiotech-journal.ru

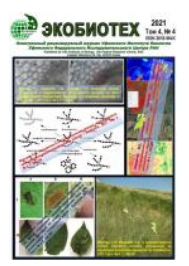

Обзор

МИКРОМИЦЕТЫ В КАРСТОВЫХ ПЕЩЕРАХ

Рябова А.С. ${ }^{*}$ Кузьмина Л.Ю., Галимзянова Н.Ф.

Уфимский Институт биологии Уфимского федерального исследовательского центра РАН, Уфра

*E-mail: alenarya@rambler.ru

Микромицеты являются неотъемлемой частью микробного сообщества пещерных экосистем, выполняют в них роль редуцентов или ведут паразитический образ жизни. Микроскопические грибы, в том числе и дрожжи, в пещерах выделяются из грунта, воздушной среды, водопроявлений, минеральных образований, со скальных поверхностей и даже с троглобионтов. По соотношению грибов разных температурных режимов и сукцессии видов можно судить о связи подземной полости с поверхностью и интенсивности поступления питательных веществ. Среди микроскопических грибов в пещерах преобладают представители - Chrysosporium, Mucor, Mortierella, Peniciliium, Trihoderma, Aspergillus, Geomyces. Микромицеты активно участвуют в геохимических преобразованиях окружающей среды, вызывают коррозию горных пород, что может представлять опасность для сохранности наскальных рисунков в декорированных полостях. Антропогенная нагрузка приводит к изменениям в составе микроскопических грибов за счет повышения трофического статуса пещерных экосистем, а также из-за возможного активного трансграничного переноса микроорганизмов посетителями. Использование подземных полостей как туристических объектов диктует необходимость разработки критериев нормирования содержания микромицетов в воздухе с учетом специфики пещер для обеспечения безопасности людей. Данный обзор обобщает накопленные данные о разнообразии и распространении микроскопических грибов в карстовых пещерах.

Ключевые слова: микромицеты м микроскопические грибы • карстовые пещеры • микробиота спелеосистем • геомикробиология

\section{MICROMYCETES IN KARST CAVES}

Ryabova A.S., Kuzmina L.Y., Galimzyanova N.F. Ufa Institute of Biology of the Ufa Federal Research Centre of the Russian Academy of Sciences, Ufa *E-mail: alenarya@rambler.ru

Micromycetes are an integral part of the microbial community of cave ecosystems, they play the role of decomposers or lead a parasitic lifestyle. Microscopic fungi, including yeast, in caves are isolated from soil, air, water, mineral formations, rock surfaces and even troglobionts. By the ratio of fungi of different temperature regimes and the succession of species, one can inference the relationship between the underground cavity and the surface and the intensity of nutrient intake. Representatives of Chrysosporium, Mucor, Mortierella, Peniciliium, Trihoderma, Aspergillus, Geomyces predominate among microscopic fungi in caves. Micromycetes are actively involved in geochemical transformations of the environment, causing corrosion of rocks, which can pose a danger to the preservation of rock paintings in decorated cavities. Anthropogenic load leads to changes in the composition of microscopic fungi due to an increase in the trophic status of cave ecosystems, as well as due to the possible active transboundary transfer of microorganisms by visitors. The use of underground cavities as tourist sites dictates the need to develop criteria for standardizing the content of micromycetes in the air, taking into account the specifics of caves to ensure the safety of people. This review is aimed at summarizing the accumulated data on the diversity and distribution of microscopic fungi in karst caves.

Keywords: micromycetes - microscopic fungi • karst caves $\bullet$ microbiota of speleosystems $\bullet$ geomicrobiology Поступила в редакиию: 21.10.2021

DOI: $10.31163 / 2618-964 X-2021-4-4-227-233$

Карстовые пещеры - естественные подземные шахты, колодцы, полости, имеющие четкие границы, сообщающиеся с земной поверхностью или замкнутые, образующиеся при выщелачивании покрывающих карстующихся пород. Особые микроклиматические и физико-химические условия [Абдуллин, Миркин, 2013], складывающиеся в пещерах, 
приводят к формированию в них специфических сообществ живых организмов, представленных бактериями, археями, микроскопическими грибами и дрожжами. Пещеры, по большей части, являются гетеротрофными экосистемами, поступление питательных веществ и энергии в них происходит за счет воздушных потоков, инфильтрационных и инфлюационных вод, немаловажный вклад вносят гравитационный и биогенный пути, а также рекреационная нагрузка [Абдуллин, 2014]. Активное внесение органических веществ внутрь пещер, установка осветительных систем способствуют изменению трофического статуса спелеосистем, следствием чего может быть развитие и сохранение в них микроскопических грибов, в том числе патогенных, образование видимых очагов роста [Хижняк и др., 2003; Мазина, Северин, 2007; Абдуллин, 2014].

Грибы в пещерах функционируют как паразиты или редуценты, зачастую совмещая эти роли. Микоризы были обнаружены лишь в небольших пещерах, куда проникают корни растений. Многие грибы, выделенные из пещер, сохраняются там, в виде спор, ожидая наступления подходящих условий для развития. Источником органического углерода для них могут стать животные троглобионты, а так же хемолитоавтотрофные бактерии как было установлено на примере шахт в Румынии или пещерах Лечугилья (Lechuguilla, CША) [Vanderwolf et al., 2013] и Мовиле (Movile, Румыния) [Barton, Northup, 2007].

Наличие среди грибов в пещерах паразитов растений подтверждает тот факт, что споры могут попадать в полости с водой и потоками воздуха. Кроме того виды, обнаруживаемые в полости, как правило, широко распространены в почве поверхности окружающего ландшафта [Hsu, Agoramoorthy, 2001; Docampo et al., 2011; Vanderwolf et al., 2013]. Видовое разнообразие грибов непосредственно в полости значительно ниже, чем на поверхности, и их число последовательно снижается при продвижении вглубь пещеры [Hsu, Agoramoorthy, 2001; Кузьмина и др., 2012]. Грибы в пещерных экосистемах являются пищей для беспозвоночных троглобионтов [Vanderwolf et al., 2013], поэтому они участвуют в распространении грибных спор в пещерах [Bastian et al., 2009].

По отношению к температурным условиям грибы в пещерах делятся на три группы: типичные мезофилы, облигатные и факультативные психрофилы (психротолерантные виды). По соотношению данных групп можно судить о сукцессии микроскопических грибов на протяжении всей полости. Наличие в пещере представителей всех трех групп говорит о постоянном пополнении микроорганизмов подземных полостей видами с поверхности [Хижняк и др., 2003].

Среди обитающих в пещерах микромицетов наиболее многочисленны представители родов Chrysosporium, Mucor, Mortieella, Peniciliium, Trihoderma, дрожжевые грибы [Хижняк, 2009]. Другие исследователи, напротив, обнаруживали в пещерах очень низкое количество дрожжей. Было выдвинуто предположение, что содержание дрожжей в пещерах находится в прямой зависимости от уровня посещаемости или присутствия животных [Jurado et al., 2010; Vanderwolf et al., 2013]. Существенным ограничением является тот факт, что проведенные исследования отображают не истинное биоразнообразие в полости, а специфику применяемых методов. В качестве примера можно привести противоречие в определении видового разнообразия микромицетов, полученного методом посева и молекулярно-генетического анализа при исследовании австралийских пещер. Это противоречие возникло из-за того, что при культивировании на лабораторных средах быстрорастущие виды подавляют медленнорастущие олиготрофные виды [Northup et al., 2000; Vanderwolf et al., 2013]. На несовершенство применяемых методов также указывает тот 
факт, что вид Pseudogymnoascus destructans (Geomyces destructans) не был обнаружен в микологических исследованиях, проведенных в Европе. Впервые данный вид был выделен в пещерах южной части Канады, а в Европе был обнаружен позже при изучении проблемы «синдрома белого носа» у летучих мышей [Vanderwolf et al., 2013].

Основная масса грибов в пещере обитает в грунте. Мозаичное распространение грибов зависит от свойств колонизируемого субстрата: доступности воды, температуры, уровня $\mathrm{pH}$, наличия питательных веществ, минерального состава, пористости и проницаемости пород. Точечный характер распределения гетеротрофных субстратов на полу пещеры и их заселение преимущественно одной популяцией грибов говорит об отсутствии межвидовой конкуренции [Vanderwolf et al., 2013].

Концентрация спор грибов в воздухе, как было показано при изучении пещер Китая, Англии и Испании, положительно коррелирует с температурой и отрицательно с влажностью и выпадением осадков, так как дожди вымывают микроорганизмы из воздуха и препятствуют их заносу в пещеру. В летнее время в пещерах Китая, Испании и Румынии численность спор в воздухе возрастала, повторяя пик на поверхности [Wang et al., 2010; Vanderwolf et al., 2013]. В пещере Нерха (Nerja, Испания) обнаружено три пика концентрации спор в воздухе - максимальный летом и меньшие весной и осенью. Различался таксономический состав микромицетов, летом преобладали несовершенные грибы (68\%), а обычно низкие концентрации спор групп Ascomycota, Bacidiomycota, Myxomycota и Oomycota увеличивались весной и осенью во время дождей [Docampo et al., 2011]. Эти данные совпадают с исследованиями, проведенными в пещерах Испании и Саудовской Аравии [Vanderwolf et al., 2013]. Наиболее часто встречающимися грибами в аэросреде пещеры Могао (Mogao, Китай) являлись представители рода Cladosporium, а не представители родов Penicillium и Alternaria [Wang et al., 2010]. В пещере Аскинская (Россия) была выявлена другая картина, вероятно, такая особенность обусловлена ее морфологией (каменный мешок), а также наличием наледи [Кузьмина и др., 2014].

Скальные поверхности пещер представляют собой наибольшие по площади участки потенциально пригодные для заселения микроскопическими грибами. Так, в пещере Нерха на стенах были обнаружены 72 вида грибов, 19 из них были представителями Ascomycota и 16 Basidiomycota [Docampo et al., 2011]. Пещерные микроорганизмы способны образовывать видимые разрастания (биопленки) на естественных субстратах при попадании на них незначительных концентраций питательных веществ. Как правило, эти биопленки представляют собой многовидовые сообщества, состоящие из различных микроорганизмов грибов, бактерий, архей, вирусов. В условиях крайней ограниченности ресурсов и неоптимальных физических параметров, которые характерны для спелеосистем, жизнедеятельность в составе таких сообществ способствует лучшей выживаемости организмов. Так, на глубине 740 метров в минералах были обнаружены гифы грибов, ассоциированные с сульфатвосстанавливающими бактериями, такая ассоциация способствовала жизнедеятельности грибов в анаэробных условиях [Drake et al., 2017]. В составе сноттита (микробной биопленки, свисающей с потолка) пещеры сернокислотного спелеогенеза Шеки-Кьех (Россия) был обнаружен темноокрашенный гриб, идентифицированный как Acidomyces acidophilus [Кузьмина и др., 2019].

Для обеспечения жизнедеятельности микроорганизмов достаточно того количества питательных веществ, которое поступает в полость вместе с инфильтрационными водами [Jurado et al., 2009]. В работе, посвященной развитию грибов в инфильтрационной воде пещеры, концентрация органических веществ в которой не превышала 5 мг/л, выявлено 
спонтанное образование биопленки аборигенных бактерий на гифах Alternaria alternata при длительном культивировании [Галимзянова и др., 2019]. Известно, что вокруг гиф формируется микосфера, состоящая из различных экзометаболитов, в ней могут располагаться бактерии [Haq et al., 2014]. Вероятно, гифы грибов играют роль каркаса при формировании биопленки. Исследование биопленок в трех пещерах Сербии показало, сходство их состава - в них обнаружены цианобактерии и водоросли (Chlorophyta и Bacillariophyta), а также грибы порядков Ascomycetes, Zygomycetes и Basidiomycetes (единственным представителем последнего была Rhizoctonia sp.). В составе белых колоний, развивающихся в пещере Doña Trinidad (Испания), были обнаружены бактерии (Pseudonocardia sp.) и грибы рода Fusarium. Наблюдалось развитие Fusarium spp. при экспериментальном внесении аммония в грунт пещеры [Stomeo et al., 2009]. B пещере Киндерлинская на остатках свечного парафина образуются многовидовые биопленки с явным преобладанием в них Penicillium aurantiogriseum, Aspergillus aureolatus и A. versicolor [Галимзянова и др., 2018]. Особенно опасны очаги развития грибов в пещерах с наскальной живописью, поскольку они воздействуют на минералы путем прямого и косвенного биомеханического выветривания [Gadd, 2007; Docampo et al., 2011].

B пещере Ласко (Lascaux, Франция) из краски наскальных рисунков были выделены микромицеты, принадлежащие родам Acremonium, Cosmospora, Exophiala, Fusarium, Geomyces, Isaria, Mortierella, Ochroconis, Penicillium [Martin-Sanchez et al, 2012]. Разрушение наскальных рисунков в пещере Святого спасителя (Holy Saviour, Италия) вызывают Cladosporium cladosporioides, Capnobotryella antalyensis, Devriesia lagerstroemiae, Teratosphaeria knoxdaviesii, Capnobotryella erdogani [Zucconi et al., 2012].

Особый интерес у исследователей вызывает вопрос об изменении численности и разнообразия микроскопических грибов под влиянием антропогенной нагрузки. Многократно отмечалось, что с ростом посещаемости в подземных полостях увеличивается численность грибов в грунте и воздухе, где она сохраняется в течение нескольких часов, особенно в летнее время [Jurado et al., 2010; Shapiro, Pringle, 2010; Docampo et al., 2011; Taylor et al., 2013; Mulec, 2014]. Так например, в пещерах Ардалес (Ardales, Испания) и Нерха после посещения небольших (до 40 человек) туристических групп концентрация грибных спор в воздухе увеличивалась в 100 раз [Docampo et al., 2011]. Наиболее часто встречались представители родов Penicillium, Aspergillus, Cladosporium [Docampo et al., 2010]. В пещере Шульган-Таш (Россия) численность микроорганизмов в воздухе возрастала в 18 раз, появлялись виды, характерные для поверхностной экосистемы, такие как Alternaria alternata, Cladosporium cladosporioides [Кузьмина и др., 2018]. На основании многочисленных исследований воздуха европейских пещер был сделан вывод, что виды рода Cladosporium приносятся с поверхности, а виды рода Penicillium попадают в воздух из грунта за счет воздушных потоков при движении посетителей [Porca et al., 2011]. Опасность переноса в пещеру микроорганизмов на теле и одежде человека заключается в том, что в этом случае чужеродные виды микроорганизмов напрямую доставляются в дальние части пещер - минуя естественные барьеры, действующие для природных агентов - воздуха и воды (то есть, по сути, происходит трансграничный перенос загрязнителей между двумя экосистемами) [Docampo et al., 2010].

В связи с повышением значимости пещер как экскурсионных объектов в начале XXI века встал вопрос о безопасности спелеосистем для человека [Docampo et al., 2011]. В пещерах обнаружены патогенные и условно патогенные виды грибов: Aspergillus flavus, 
A. japonicas, A. niger, A. versicolor, A. ustus, Fusarium oxysporym, F. solani, Histoplasma capsulatum, Penicillium marneffei, Trichoderma viride [Jurado et al., 2010; Taylor et al., 2013].

На основе объединенных данных по европейским экскурсионным пещерам было предложено использовать индексы состояния аэробиоты, характеризующие степень нарушения экосистемы. Были выделены пять категорий: безопасное ( $\left.<50 \mathrm{KOE} / \mathrm{m}^{3}\right)$, пограничное $\left(50-100 \mathrm{KOE} / \mathrm{M}^{3}\right)$, угрожающее $\left(150-500 \mathrm{KOE} / \mathrm{m}^{3}\right)$, загрязненное (500-1000 $\left.\mathrm{KOE} / \mathrm{M}^{3}\right)$ и состояние опасного загрязнения (>1000 KOE/ $\left.\mathrm{M}^{3}\right)$ [Porca et al., 2011]. Дальнейшие исследования выявили, что данные категории оказались неприменимы для крупных полостей. Поэтому было выдвинуто предложение разделять пещеры по распространению в них грибных пропагул на две группы: «самоочищающиеся» и «не самоочищающиеся». «Самоочищающиеся пещеры» характеризуются высокой численностью грибов в воздухе у входа, которая резко снижалась по мере увеличения продвижения в глубь полости. Пещеры, испытывающие интенсивное воздействие поверхностной экосистемы на всей протяженности, в которых, соответственно, не снижается численность микроорганизмов в воздухе дальних залов, относятся к «не самоочищающимся» [Leplat et al., 2019].

Микробные сообщества пещер, типичными обитателями которых являются микроскопические грибы, крайне разнообразны, их состав зависит как от географического положения пещеры, так и от геологических характеристик полости. Основная масса микромицетов в подземных полостях представлена митоспоровыми грибами. Однако их состав является специфичным и может варьировать в зависимости от конкретных условий, складывающихся в пещерах. Микромицеты чутко реагируют на изменение физикохимических параметров спелеосреды, а также ее трофического статуса, что делает характеристики комплексов грибов удобными критериями для оценки состояния экосистемы пещер. Изучение микробиоты экскурсионных пещер выявило, что антропогенная нагрузка приводит к изменению численности и видового состава микроорганизмов подземных полостей. Проникновение в полости чужеродных видов (в том числе патогенных для человека) вызывает необходимость разработки критериев нормирования уровня рекреационной нагрузки, способствующей поддержанию функционирования экосистемы полости в безопасном режиме.

Работа выполнена в рамках государственного задания Минобрнауки России № 07500326-19-00 по теме № АААА-А18-118022190098-9. Микробиологические исследования проводятся на оборудовании ЦКП «Агидель» УФИЦ РАН.

\section{СПИСОК ЛИТЕРАТУРЫ}

1. Абдуллин Ш.Р. Разнообразие трофической структуры экосистем пещер // Успехи современной биологии 2014. Т. 134. № 2. С. 192-204.

2. Абдуллин Ш.Р., Миркин Б.М. Экосистемный анализ пещер Республики Башкортостан // Вестник академии наук РБ. 2013. Т. 18. № 2. С. 5-12.

3. Галимзянова Н.Ф., Кузьмина Л.Ю., Рябова А.С. и др. Развитие микроскопических грибов при культивировании в инфильтрационной воде пещеры Шульган-Таш // Экобиотех. 2019. T. 2. № 3. C. 219-222. DOI: 10.31163/2618-964X-2019-2-3-219-222

4. Галимзянова Н.Ф., Рябова А.С., Кузьмина Л.Ю. Видовой состав микроскопических грибов, образующих видимые колонии в пещере Киндерлинская (Южный Урал) // Экобиотех. 2018. T. 1. № 1. C. 25-32. DOI: 10.31163/2618-964X-2018-1-1-25-32 
5. Кузьмина Л.Ю., Галимзянова Н.Ф., Абдуллин Ш.Р. и др. Микробиология пещеры Киндерлинская (Южный Урал) // Микробиология. 2012. Т. 81. № 2. С. 273-281.

6. Кузьмина Л.Ю., Галимзянова Н.Ф., Гильванова Е.А. и др. Ацидофильные микробные сообщества пещеры Шеки-Кьех (Северный Кавказ, Чеченская Республика) // Экобиотех. 2019. T. 2. № 4. C. 520-524. DOI: 10.31163/2618-964X2019-2-4-520-524

7. Кузьмина Л.Ю., Галимзянова Н.Ф., Рябова А.С. и др. Предварительные данные по влиянию суточной динамики микроклимата, рекреационной нагрузки на содержание микроорганизмов в воздухе пещеры Шульган-Таш (Южный Урал) // Пещеры. Пермь, 2018. Вып. 41. С. 110-114.

8. Кузьмина Л.Ю., Червяцова О.Я., Галимзянова Н.Ф. и др. Аэробиологическое исследование пещеры Аскынской ледяной (Южный Урал) // Спелеология и спелеостология. Сборник материалов V Международной научной конференции. Наб. Челны: НИСПТР, 2014. С. 303-309.

9. Мазина С.Е., Северин А.В. Разработка метода реабилитации антропогеннотрансформированных подземных систем на примере Новоафонской пещеры // Экологическая химия. 2007. Т. 3. № 16. С. 175-181.

10. Хижняк С.В. Микробные сообщества карстовых пещер Средней Сибири: автореф. дис. д-ра биол. наук (03.00.16). Красноярск. 2009. Красноярский государственный аграрный университет. $33 \mathrm{c}$.

11. Хижняк С.В., Таушева И.В., Березикова А.А. и др. Психрофильные и психротолерантные гетеротрофные микроорганизмы карстовых полостей средней Сибири // Экология. 2003. № 4. С. 261-266.

12. Barton H.A., Northup D.E. Geomicrobiology in cave environments: past, current and future perspectives // Journal of Cave and Karst Studies. 2007. V. 69 (1). P. 163-178.

13. Bastian F., Alabouvette C., Jurado V. et al. Impact of biocide treatments on the bacterial communities of the Lascaux Cave // Naturwissenschaften. 2009. V. 96 (7). P. 863-868. DOI: $10.1007 / \mathrm{s} 00114-009-0540-\mathrm{y}$

14. Docampo S., Trigo M.M., Recio M. et al. Fungal spore content of the atmosphere of the Cave of Nerja (southern Spain): Diversity and origin // Science of the Total Environment. 2011. V. 409 (4). P. 835-843. DOI: 10.1016/j.scitotenv.2010.10.048

15. Docampo S., Trigo M.M., Recio M. et al. High incidence of Aspergillus and Penicillium spores in the atmosphere of the cave of Nerja (Malaga, southern Spain) // Aerobiologia. 2010. V. 26 (2). P. 89-98. DOI: 10.1007/s10453-009-9146-2

16. Drake H., Ivarsson M., Bengtson S., et al. Anaerobic consortia of fungi and sulfate reducing bacteria in deep granite fractures // Nature communications. 2017. V. 8 (1). P. 1-10. DOI: 10.1038/s41467-017-00094-6

17. Gadd G.M. Geomycology: biogeochemical transformations of rocks, minerals, metals and radionuclides by fungi, bioweathering and bioremediation // Mycological Research. 2007. V. 3 (1). P. 3-49. DOI: 10.1016/j.mycres.2006.12.001

18. Haq I.U., Zhang M., Yang P., et al. The interactions of bacteria with fungi in soil: emerging concepts // Advances in Applied Microbiology. 2014. V. 89. P. 185-215. DOI: 10.1016/B978-0-12-800259-9.00005-6

19. Hsu M.J., Agoramoorthy G. Occurrence and diversity of thermophilous soil microfungi in forest and cave ecosystems of Taiwan // Fungal diversity. 2001. V. 7. P. 27-33. 
20. Jurado V., Fernandez-Cortes A., Cuezva S. et al. The fungal colonisation of rock-art caves: experimental evidence // Naturwissenschaften. 2009. V. 96 (9). P. 1027-1034. DOI: $10.1007 / \mathrm{s} 00114-009-0561-6$

21. Jurado V., Porca E., Cuezva S., et al. Fungal outbreak in a show cave // Science of the $\begin{array}{llllll}\text { Total Environment. 2010. } & \text { V. } 408 \quad \text { (17). } & \text { P. } & \text { 3632-3638. }\end{array}$ DOI: $10.1016 /$ j.scitotenv.2010.04.057

22. Leplat J., François A., Touron S., et al. Aerobiological behavior of Paleolithic decorated caves: a comparative study of five caves in the Gard department (France) // Aerobiologia. 2019. V. 35 (3). P. 105-124. https://link.springer.com/article/10.1007/s10453-018-9546-2

23. Martin-Sanchez P.M., Novakova A, Bastian F., et al. Two new species of the genus Ochroconis, O. lascauxensis and O. anomala isolated from black stains in Lascaux Cave, France // Fungal biology. 2012. 116 (5). P. 574-589. DOI: 10.1016/i.funbio.2012.02.006

24. Mulec J. Human impact on underground cultural and natural heritage sites, biological parameters of monitoring and remediation actions for insensitive surface: Save of Slovenian Show cave // Journal for Nature Conservation. 2014. V. 22 (2). P. 132-141. DOI: 10.1016/j.jnc.2013.10.001

25. Northup D.E., Dahm C.N., Melim L.A., et al. Evidence for geomicrobiological interactions in Guadalupe caves // Journal of Cave and Karst Studies. 2000. V. 62 (2). P. 80-90.

26. Porca E., Jurado V., Martin-Sanchez P.M., et al. Aerobiology: An ecological indicator for early detection and control of fungal outbreaks in caves // Ecological Indicators. 2011. V. 11 (6). P. 1594-1598. DOI: 10.1016/j.ecolind.2011.04.003

27. Shapiro J., Pringle A. Anthropogenic influences on the diversity of fungi isolated from caves in Kentucky and Tennessee // American Midland Naturalist. 2010. V. 163 (1). P. 76-86. DOI: 10.1674/0003-0031-163.1.76

28. Stomeo F., Portillo M.C., Gonzalez J.M. Assessment of bacterial and fungal growth on natural substrates: consequences for preserving caves with prehistoric painting // Current Microbiology. 2009. V. 59 (3). P. 321-325. DOI: 10.1007/s00284-009-9437-4

29. Taylor E.L.S., Stoianoff M.A.R., Ferreira R.L. Mycological study for a management plan of a neotropical snow cave (Brazil) // International Journal of Speleology. 2013. V. 42 (3). P. 267-277. DOI: 10.5038/1827-806X.42.3.10

30. Vanderwolf K.J., Malloch D., McAlpine D.F. et al. A world review of fungi, yeasts and slime molds in caves // International Journal of Speleology. 2013. V. 42 (1). P. 77-91. DOI: $10.5038 / 1827-806 X .42 .1 .9$

31. Wang W., Ma X., Ma Y., et al. Seasonal dynamics of airborne fungi in different caves of the Mogao Grottoes, Dunhuang, China // International Biodeterioration and Biodegradation. 2010. V. 64 (6). P. 461-466. DOI: 10.1016/j.ibiod.2010.05.005

32. Zucconi L., Gagliardi M., Isola D. et al. Biodeterioration agents dwelling in or on the wall paintings of the Holy Saviour's cave (Vallerano, Italy) // International Biodeterioration and Biodegradation. 2012. V. $70 . \quad$ P. 40-46. DOI: $10.1016 /$ j.ibiod.2011.11.018 